kuolleita henkilöitä.

Kirjailija, toimittaja Ville Ropponen esitteli Suomalaisten kansojen vapautusliiton eli Sofinsalaliittojuttua, joka kehiteltiin kokoon vuosina 1931-34. Järjestön väitettiin suunnitelleen Neuvostoliiton suomensukuisten kansojen yhdistämistä Suomen alaiseksi "protektoraatiksi" aina Karjalasta Jeniseijoelle Siperiaan asti. Sofinsalaliiton vuoksi vangittuja teloitettiin myöhemmin Stalinin vainoissa. Suuren terrorin aikana Sofin-salaliittoa käytettiin lisäksi yhtenä tuomion osaperusteena. Tällöin siihen yhdistettiin jopa tuhansia ihmisiä. Jukka Rislakin puheenvuoro suomalaisten vangitsemisista, kuulusteluista ja tuomioista julkaistaan ohessa.

Seminaari päättyi keskusteluun, johon osallistuivat Ilta-Sanomien toimittaja Arja Paananen, toimittaja Lea Pakkanen, kirjailija-toimittaja Ville Ropponen ja kirjailija Ville-Juhani Sutinen.

Seminaari on kokonaisuudessaan katsottavissa YouTubessa osoitteessa:

https://youtu.be/1OxdgOT_5Ek

Kanerva Cederström

\title{
Suomalaiset Stalinin suuressa vainossa
}

Tämän kirjoituksen taustalla on Helsingissä järjestetyn Gulag ja Suomi - historia ja muisti -seminaarin järjestäjien pyyntö puhua suomalaisten kohtaloista Stalinin vainoissa. Monet tässä kirjoituksessa käyttämäni tiedot ihmiskohtaloista ovat peräisin venäläisistä arkistoista ja käytimme niitä, kun kirjoitimme Eila Lahti-Argutinan kirjaa Meillä ei kotia täällä. Suomalaisten loikkarien joukkotuho Uralilla 1938 (Otava 1997). Lisätietoja olen etsinyt Suomessa ja ulkomailla ilmestyneistä tietokirjoista ja muistelmista. Olen myös haastatellut entisiä gulag-vankeja itse. Nämä haastattelut ovat kokoelmassani Kansan arkistossa.

Suuren vainon niin sanotut kansalliset operaatiot vuosina 1937-38 kohdistuivat erityisen ankarina kahteen vähemmistöryhmään, suomalaisiin ja puolalaisiin. Kun tarkastellaan kaikkia tuolloin koko Neuvostoliitossa tuomittuja poliittisia pidätettyjä, käy ilmi, että 51 prosenttia oikeuden eteen joutuneista sai kuolemantuomion. ${ }^{1}$ Tilastoista voi myös päätellä, että suomalaisista vangituista ja tuomituista noin 89 prosenttia teloitettiin. Tämä tapahtui muutaman kuukauden ajanjaksona vainon huippukaudella vuosina 1937-38 ja olisi korkein luku suhteessa kaikkiin muihin vähemmistökansallisiin ryhmiin - sillä varauksella, että venäläisiin tilastoihin voi luottaa. Minun lisäkseni myös muut ovat laskeneet ja arvioineet, että selvästi yli 80 prosenttia suomalaisista tuomituista sai tuolloin kuolemantuomion. Noin 80 prosenttia on myös puolalaisten ja virolaisten suhdeluku. Kaikkien vähemmistökansallisuuksien teloituskeskiarvo oli 73,6 prosenttia.

Pidätysluvuissa suomalaiset sijoittuivat Neuvostoliitossa vasta sijalle 16. Teloitettujen vähemmistökansojen joukossa suomalaiset olivat määrällisesti eli absoluuttisin luvuin kuudennella sijalla, mutta teloitusten suhteellinen osuus nostaa suomalaiset kärkeen. Tilastot vahvistavat nobelisti Czesław Miłoszin havainnon siitä, että venäläiset eivät luottaneet muiden kansallisuuksien kommunisteihin, etenkään puolalaisiin. Numeroiden valossa on selvää, ettei suomalaisiinkaan luotettu.

Joillakin paikkakunnilla tapahtui suuria suomalaisten verilöylyjä. Olen esimerkiksi laskenut ${ }^{2}$, että yhtenä maaliskuisena yönä 1938 Tšeljabinskissä ammuttiin yli 200 suomalaista naista ja miestä. Teloituksia tapahtui samana yönä myös Sverdlovskissa. Syyskuussa 1938 Sisäasiain kansankomissariaatti NKVD ahkeroi myös Neuvosto-Karjalassa. Sen suosituksesta tuomittiin yhtenä päivänä 500 "Suomen vakoojaa"; viitenä perättäisenä päivänä kaikkiaan 1 382 suomalaista, joista 1353 tuomittiin kuolemaan.

Edellisenä vuonna NKVD:n johtaja Nikolai Ježov oli määrännyt, että synnyinmaan pettureiden vaimotkin oli vangittava ja kyydittävä. Pidätetty sai kotietsinnän jälkeen ottaa mukaan alusvaatekerran, pyyhkeen, saippuan ja 50 ruplaa rahaa. Yli 15-vuotiaat lapset oli tuomittava 5-8 vuodeksi vankeuteen, koska eivät olleet ilmiantaneet vanhempiaan. Yli 16-vuotiaat voitiin lähettää gulag-leireille. Vaille vanhempiaan jääneet lapset siirrettiin lastenkoteihin, työpalvelukseen tai hallinnon näkökulmasta luotettavien henkilöiden kasvatettaviksi. Sisarukset erotettiin toisistaan, ja usein heidän nimensä muutettiin.

Jo tuolloin olivat voimassa muutetun rikosoikeuden seuraavat pykälät: terroristijärjestöjen juttujen käsittelyyn saa käyttää enintään 10 
päivää; käsittely tapahtuu ilman syyttäjän ja puolustusasianajajan läsnäoloa; valituksia ja armahdusanomuksia tuomioista ei oteta vastaan ja ankarin tuomio eli teloittaminen pannaan täytäntöön viipymättä tuomion julistamisen jälkeen.

Teloituksista Ježov antoi myös ohjeen: jos vanki pystyy seisomaan jaloillaan, hänet tulee ampua. Vuodesta 1937 alkaen NKVD:1lä oli myös virallinen lupa kiduttaa vankeja. Se oli Stalinin mukaan asiallinen ja oikea menetelmä kansanvihollisia vastaan. Myös 12-vuotiaita voitiin rankaista ja 18 vuotta täyttäneitä tuomita kuolemaan. Ježov ohjeisti myös, mistä rikoksesta mikin ryhmä oli tuomittava. Suomalaiset tuomittiin lähinnä rikoslain pykälän 58 mukaan, jolloin tuomio tuli vakoilusta, diversiosta eli sabotaasista, neuvostovastaisesta propagandasta, vastavallankumouksellisesta nationalismista tai yrityksestä ylittää raja luvatta eli pakoyrityksestä. Neuvosto-Karjalassa vangituista tuhansista suomalaisista yli 70 prosenttia syytettiin vakoilusta Suomen hyväksi. Näin ollen NeuvostoKarjalassa olisi ollut melkein kaksi ja puoli tuhatta väitettyä Suomen vakoojaa.

Alueelliset kolmikot eli troikat antoivat ankaria rangaistuksia hallinnollisina päätöksinä. Kaksikko eli dvoika Moskovassa puolestaan yleensä vahvisti ne suljetuin ovin, syytettyjä näkemättä ja kuulematta. Troikkaan kuuluivat NKVD:n paikallishallinnon päällikkö, puolueen aluekomitean sihteeri ja ylisyyttäjä. Dvoika merkitsi Neuvostoliiton NKVD:n ja ylisyyttäjän komissiota. Alueille oli määrätty vangitsemis- ja teloituskiintiöt. Näin ollen oli siis pakko löytää tietty määrä tuholaisia ja kansanvihollisia. Suuren vainon aikana alueelliset troikat käsittelivät yli satatuhatta juttua kahdessa kuukaudessa. Moskovassa asiat päätettiin niputtamalla jopa satoja syytettyjä, jolloin yhtä tapausta kohden ei voinut montaa minuuttia käyttää. Keskimäärin kesästä 1937 syksyyn 1938 Neuvostoliitossa teloitettiin yli 1500 ihmistä päivässä. Sitä voi pitää todellisena teloitusliukuhihnana. NKVD:n virkailijoiden kuntoisuusluokka määräytyi sen mukaan, montako tunnustusta he yhden yön aikana saivat puristettua vangituista. Oli "stahanovilaisia" tutkijoita, jotka pystyivät kuulustelemaan toistakymmentä vangittua yhden vuorokauden aikana ja kirjoittamaan heistä paperit.

Moskova valitti, että puhdistukset etenivät liian hitaasti. Juttujen käsittelyä piti nopeuttaa ja vankimäärää vähentää. Oli kuitenkin monenlaisia logistisia vaikeuksia eikä niin suureen vangittujen ja teloitusten määrään ei oltu varauduttu. Vankilat täyttyivät. Myös vartijoista, junista ja leireistä oli pulaa. Ruokinta tuotti vaikeuksia ja myös joukkohaudat täyttyivät. Vaikuttaa siltä, että lisää tilaa vankiloihin tehtiin teloituksin. Ježov pyysi joulukuussa 1937 Molotovilta kiireesti ennakoimattomien lisätehtävien nojalla budjetista 30 miljoonan ruplan edestä lisää varjoja.

NKVD:n kirjeenvaihdosta ilmenee, että paikallisosastot pyysivät lähettämään lisää Nagan-revolverin patruunoita. Esimerkiksi marraskuussa 1937 Tšistopolin vankilassa päivätyn asiakirjan mukaan allekirjoittaneet eli joukko upseereita vahvistavat, että 84 kappaletta revolverin patruunoita on poistettu kirjanpidosta. Ne olivat kuluneet Tatarstanin NKVD:n troikan määräämän operaation tarkoitusten toteuttamiseen. Operaatio koski syytettyjen ampumista 26.8.1937, 21.9.1937 ja 26.9.1937. Keväällä 1938 Ježov kehotti nopeuttamaan myös "suomalaisoperaatiota". Syksyllä puoluejohto kiittikin NKVD:tä tehokkuudesta. Marraskuussa kuitenkin Ježov jo erotettiin ja vangittiin.

Jokaisen vangin oli tunnustettava rikos ja allekirjoitettava kuulustelupöytäkirjan jokaikinen sivu. Prosessia hidasti se, etteivät kaikki heti suostuneet tunnustamaan. NKVD:n työntekijät ovat kertoneet, että hyväuskoiset suomalaiset usein tunnustivat melko nopeasti ja ilman väkivaltaa saavuttaakseen jotain etua. Huhuttiin esimerkiksi, että ollessaan yhteistyöhaluisia he olisivat päässeet Suomeen. Myös ruualla ja juomalla houkuteltiin. Raportoitiin myös muiden tunnustuksista. Kuulusteluissa käskettiin aina nimetä muita mahdollisia vakoojia ja luetella ystävät ja sukulaiset. Näin tuli paljastetuksi lisää rikollisia. Se, että ilmianto tapahtui painostuksen alla, oli heti riittävä ja raskauttava todiste tämän syyllisyydestä. Suomalaiset siirtolaiset ja loikkarit olivat yleensä myös ns. "vähälukutaitoisia" venäjän kielellä eivätkä aina ymmärtäneet mitä allekirjoittivat.

Monia oli kuitenkin pehmitettävä, tosin ei välttämättä hakkaamalla, sillä oli käytössä muitakin keinoja. Kuulustelut olivat pitkiä ja ne tapahtuivat yleensä yöllä. Kuulustelijat vaihtuivat. Pidätetyn ei annettu nukkua päivälläkään, joten tämä väsyi pian armottomasti. Nukahtanut herätettiin heittämällä päälle kylmää vettä. Kuulusteltava joutui istumaan kovalla selkänojattomalla jakkaralla häntäluunsa päällä, jalat suorina. Asento tuli nopeasti hyvin kivuliaaksi. Näin sai kuulusteltavaa istuttaa jopa 180 tuntia. Toinen yleinen keino ainakin suomalaisten kohdalla oli stoika eli seisottaminen. Pidätetty saattoi seistä jopa viisi tai kymmenenkin päivää kasvot seinään päin nojaamatta kuitenkaan seinään. Leipää ja suolaa annettiin, mutta vettä ei. Jalat turposivat 
niin, ettei vanki voinut enää käyttää kenkiä. Jotkut kertovat, että vankeja pehmitettiin myös niin, että heidän päähänsä tiputettiin vesipisaroita jopa vuorokausien ajan. Joitakin valehirtettiin. Eräs suomalaismies teki 1938 valituksen, joka päätyi talteen mappien uumeniin. Sen mukaan hänelle ei annettu mahdollisuutta levätä, nukkua, kymmeneen vuorokauteen. Häntä piestiin, uhkailtiin ja hänen päällensä kaadettiin päälle kylmää vettä. Mies myös kirjoittaa allekirjoittaneensa valheellisen pöytäkirjan. Punaupseeri Viljam Salo tunnustautui vuonna 1933 Suomen vakoojaksi. Hän sai kirjata tunnustuksensa lopuksi: "Tunnustamiseen minut johdatti sairaalloinen oloni ja heikkous, tunnen, että jos tätä jatkuu, koituu siitä minulle ennenaikainen hauta. En kestäisi pidempään, kuolisin."

Kellonajat merkittiin pöytäkirjoihin, ja niissä huomiota herättää se, että kuulustelut, jotka kestivät useita tunteja, tuottivat joskus hämmästyttävän vähän paperia. Herää ilmeinen kysymys, mitä kuulustelun aikana tapahtui. Joskus pöytäkirjoihin on kuulusteluun merkitty pieni tauko. Mitä sen aikana tehtiin? Usein pöytäkirjojen perusteella voi todeta, että kolmatta tai neljättä kertaa samaa asiaa kysyttäessä vanki myöntääkin kaiken tehden "täydellisen tunnustuksen".

Myös alaikäisiä todistettiin syyllisiksi. Esimerkiksi Veikko Ollikainen oli tullut Suomesta 12-vuotiaana ja "saanut vakoilutehtäviä". Hänet ammuttiin Karjalassa, kun hän yritti paeta. Samoin 12-vuotiaana Suomesta lähteneeltä Siiri Hämäläiseltä tiukattiin, kuka hänet oli värvännyt. Hän sai kymmenen vuoden leirituomion.

Kuulustelut ja tunnustukset olivat suorastaan kafkamaisia. Niissä oli oma logiikkansa ja niistä oli mahdoton selvitä. Heti aluksi saatettiin pyytää rehellisesti kertomaan, milloin Suomen tiedustelulaitos oli värvännyt henkilön vakoojaksi. Tai saatettiin kysyä: "miten nationalistinen toimintanne ilmenee? Tai sanoa: "Te annatte väärän todistuksen. Kehotamme puhumaan totta ja pysymään asiassa". Usein kuulusteluissa ehdotettiin kiistämisen lopettamista tai pyydettiin esittämään todisteita omasta vallankumouksellisesta toiminnasta.

Rikoksia pidettiin siis ennalta selvinä. Eräskin kuulustelu eteni seuravalla tavalla:

- Mainitkaa kaikki sukulaisenne Suomessa ja heidän asuinpaikkansa.

- (Kuulusteltava mainitsee.)

- Miten piditte heihin yhteyttä?

- En ole pitänyt heihin mitään yhteyttä.

- Miten sitten voitte tietää heidän asuinpaikkansa?

Tai kuten eräässä toisessa kuulustelussa kuulustelija toteaa: "Olette pidätettynä neuvostovastaisen toiminnan lietsonnasta aktiivisena osanottajana. On kylliksi kvalitatiivista materiaalia, joka täysin vahvistaa syyllisyytenne. Siksi kiertelyt ovat turhia." Tämän jälkeen kuulusteltava puolestaan tunnustaa: "Tunnustan, että olen osallistunut aktiivisesti neuvostovastaiseen työhön (...)...”. Kolmannessa puolestaaan tarjotaan "tilaisuutta kertoa omasta neuvostovastaisesta käytännön työstänne", johon kuulusteltava vastaa kertomalla, että "ennen kaikkea päädyin käyttämään hyväkseni neuvostovastaisia kansallismielisiä mielialoja (...)”. Eräässä kuulustelussa puolestaan kysyttiin millaisiin teollisuusyrityksiin kuulusteltava loi diversioryhmiä, johon vastaus kuului: "Kaganovitšille nimetyssä GPZ-tehtaassa ja kolmannessa Stalinille nimetyssä tehtaassa... Tehtävänä oli sopivalla hetkellä toteuttaa terroristisia toimia (...)". Eräässä kuulustelussa puolestaan kehotettiin lopettamaan kiertely ja antamaan täsmällisiä todisteita. Kuuusteltava vastasi seuraavaa: "Pitkän ja voimallisen kiertelyn jälkeen ymmärsin, että on mahdotonta kätkeä tutkijoilta osanottoni kansallismielisen vastavallankumouksellisen järjestön toimintaan, ja päätin kertoa totuuden."

Eräs ilmeisesti loppuun asti rääkätty suomalaismies tunnusti 1938 aiheuttaneensa räjähdyksen tehtaalla:

- Mistä saitte räjähdysaineen?

- Sovin siitä panostajan kanssa.

- Ettehän te osaa venäjääkään.

- Sovin siitä käsimerkeillä.

Kun yleensä ei ollut mitään varsinaista rikosta - ja sen tiesivät tšekistitkin - saattoi kuulustelu mennä tähän tapaan:

- Tiedotitte ulkomaille, että tuttavanne on saanut kahden vuoden tuomion pakoyrityksestä.

- Kyllä, kirjoitin siitä kirjeessä. Ei kaksi vuotta ole niin pitkä tuomio, etteikö siitä voisi kertoa. ${ }^{3}$

- Mistä tiedätte, että hän sai kaksi vuotta?

- Hänen vaimonsa kertoi.

- Millä voitte todistaa, että hän puhui totta?

- Hän kertoi kaiken minulle yksityiskohtaisesti, samoin hänen miehensä vapauduttuaan.

- Ne eivät ole todisteita. He valehtelivat teille.

- Heillä ei ollut mitään syytä valehdella minulle.

- Syyllisyytenne väärien tietojen levittämiseen ulkomaille on täten todistettu.

Tai kuten toinen esimerkissä, jossa kotietsinnässä oli todettu kuulusteltavan asunnossa olevan ulkomaisia vieraskielisiä lehtiä, niin että siellä käyneet ystävät saattoivat lukea niitä. Kuulusteltava vastaa syytökseen ja kuulustelu etenee seuraavasti: 
- Mutta ystäväni eivät osaa mitään ulkomaan kieliä eivätkä he osoittaneet mitään mielenkiintoa lehtiä kohtaan.

- Voitteko vakuuttaa etteivät he osaa kieliä?

- Tunnen heidät pitkältä ajalta ja tiedän, etteivät he osaa mitään vierasta kieltä.

- Miten todistatte sen?

- Kysykää heiltä itseltään ja he kertovat sen.

- He voivat väittää mitä vain mutta itse asiassa osaavatkin kieliä. Miten voitte todistaa, etteivät osaa?

- Voin kertoa teille etteivät osaa, mutten tietenkään voi todistaa.

- Tämä on tärkeä tunnustus. Te väitätte jotain mitä ette voi todistaa...

Näin oli syyllisyys taas osoitettu toteen, kuten seuraavassakin esimerkissä:

- Eikö olisi parasta, että lakkaisit näyttelemästä viatonta ja kirjoittaisit nimesi alle.

- Mutta eihän tämä ole totta. Kuinka voitte vaatia, että allekirjoittaisin tällaista?

- Olette itse lukenut Ruhasen tunnustukset. Eikä meillä ole mitään syytä epäillä niiden todenperäisyyttä.

- Mutta ne eivät ole totta! Tiedätte itse paremmin kuin minä, etteivät ne ole totta.

- Entä jos kutsun Ruhasen tähän huoneeseen, ja hän sanoo teille itse jokaisen sanansa olevan totta?

- En usko ikinä, että hän tekee niin. Ja vaikka tekisinkin, voin todistaa teille milloin vain, että hän valehtelee. Kutsukaa hänet!

- Turha vaiva. Kirjoitatte alle ilmankin.

- Mutta eihän mitään tällaista ole koskaan ollut.

- Ei. Mutta näin olisi voinut olla!

Asiakirjoista voi löytää laajan kirjon suomalaisten tekemiä rikoksia, jotka "todistettiin" ja "tunnustettiin": oli muun muassa parjattu puoluetta ja neuvostovaltaa, kehuttu Suomea ja fasistista Saksaa, odotettu sotaa Neuvostoliittoa vastaan, koottu tietoa mielialoista, puna-armeijasta ja sotateollisuudesta. Syytöksissä myös kokonaisia perheitä oli lähetetty perustamaan vakoiluryhmiä, vesiä oli jäädytetty putkissa ja kattiloissa, makkaratäytteeseen oli heitetty lasinpaloja ja nauloja, rataa rikottu niin, että juna putosi kiskoilta. Joku oli saanut tehtäväkseen polttaa Karjalan metsät tai pilannut moottoreita tiputtamalla hiekkaa laakereihin. Ida Vilkman sai kuolemantuomion siitä syystä, että oli saanut tehtaalla aikaan tulipalon itsesytytyksenä jättämällä yhteen paikkaan bensaa, öljyä ja riepuja. Viktor Alhonen puolestaan tuomittiin teloitettavaksi, koska oli valanut betonista 10 senttiä liian pitkät portaat. Salli Lappalainen taas tuomittiin siitä, että hän oli hitsannut huonosti auton runkoa niin, että auto on palannut pian taas remontoitavaksi. Hän oli myös aiheuttanut nostokorin ja sen lastin putoamisen niin, että tehtaalla on syntynyt seisokki. Eräällä toisella naisella tuomion osasyyksi todettiin se, että hän oli kuulemma yrittänyt paeta sukellusveneellä Neuvostoliitosta Laatokan kautta.

Eräs suomalaismies, joka tuomittiin kuolemaan vaimonsa kanssa 1938, tunnusti seuraavaa: "Teimme huonolaatuisia betonivalumuotteja. Hyväksyimme Sergei Kirovin murhan. Suunnittelimme tehtaan räjäyttämistä. Laskimme väärin rakennuksen perustan." Eräs mies puolestaan tunnusti jopa tappaneensa Stalinin. Täydestä ei mennyt kuitenkaan sen suomalaisen tunnustus, joka sanoi räjäyttäneensä rautatieaseman. Se oli jo liian paksua kuulustelijalle, joka sattui olemaan kotoisin kyseisestä kaupungista ja tiesi, että asema seisoi yhä ehjänä paikallaan.

Kaikki esimerkkini ovat suuren vainon ajalta 30-luvun lopulta. Vaikka kuolemantuomioita annettiinkin ehkä myöhemmin vähemmän, on muistettava, että myös sotavuodet olivat syrjityille ja luottamuspulasta kärsiville Neuvostoliiton suomalaisille erittäin raskasta aikaa. Sodan jälkeen alkoivat pitkät, 25 vuoden vankileirituomiot yleistyä. Tosin myös hengissä selvinneitä alettiin vapauttaa joitakin vuosia Stalinin kuoleman eli vuoden 1953 jälkeen.

\section{Jukka Rislakki}

\section{Viitteet:}

1 Tarkemmin tietoihin uhrien lukumääristä ja kansallisesta jakautumisesta voi tutustua muun muassa seuraavissa lähteissä: Danilov P.: Stalinizm i Sovetskoe obštšestvo. Problemy istorii massovyh polititsheskih repressii v SSSR. Materialy konferentsii. Krasnodar 2004; Reabilitatsija, kak eto bylo. Dokumenty Preziudiuma TsK KPSS i drugie materialy, Tom 1, Tom 2, MFD, Moskova 2000, 2003; Gurjanov A.: Repressii protiv poljakov i polskih graždan, Zvenia, Moskova 1997; Jānis Riekstiņš: PSRS iekšlietu tautas komisariāta "Latviešu operācija" (1937-1938). Latvijas Universitāte, Riika 2012.

2 Laskin tiedon arkisto-, haastattelu- ja kirjallisuustietojen pohjalta teokseen Rislakki Jukka ja Lahti-Argutina Eila: Meillä ei kotia täällä. Suomalaisten loikkarien joukkotuho Uralilla 1938. Otava 1997. Tarkennettuun laskelmaan Helsingin Sanomia varten (Rislakki: Verilöyly Uralilla. HS 12.3.2017) sain 2017 käyttää 
muun muassa Siirtolaisuusinsituuttiin tallennettua Lahti-Argutinan kokoamaa suomalaisten repressoitujen luetteloa.

3 Alle 10 vuoden tuomioita pidettiin mitättömän lievinä. Esimerkisi virolainen Jaan Kross sanoi häntä Komissa kuulustelleelle majurille olevansa syyttömänä tuomittu. Majuri piti asiaa itsestään selvänä: "Muuten teille olisi annettu vähintään 10 vuotta. Mutta annettiin vain viisi." 